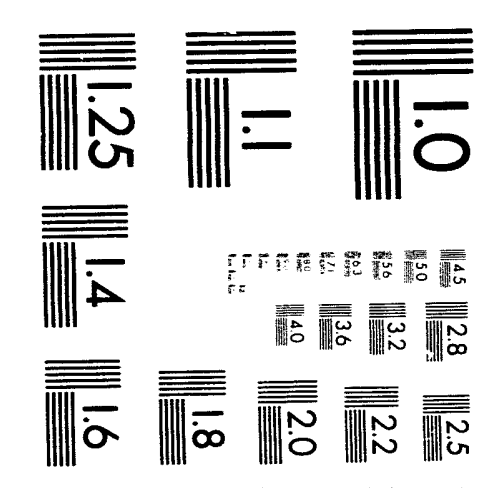



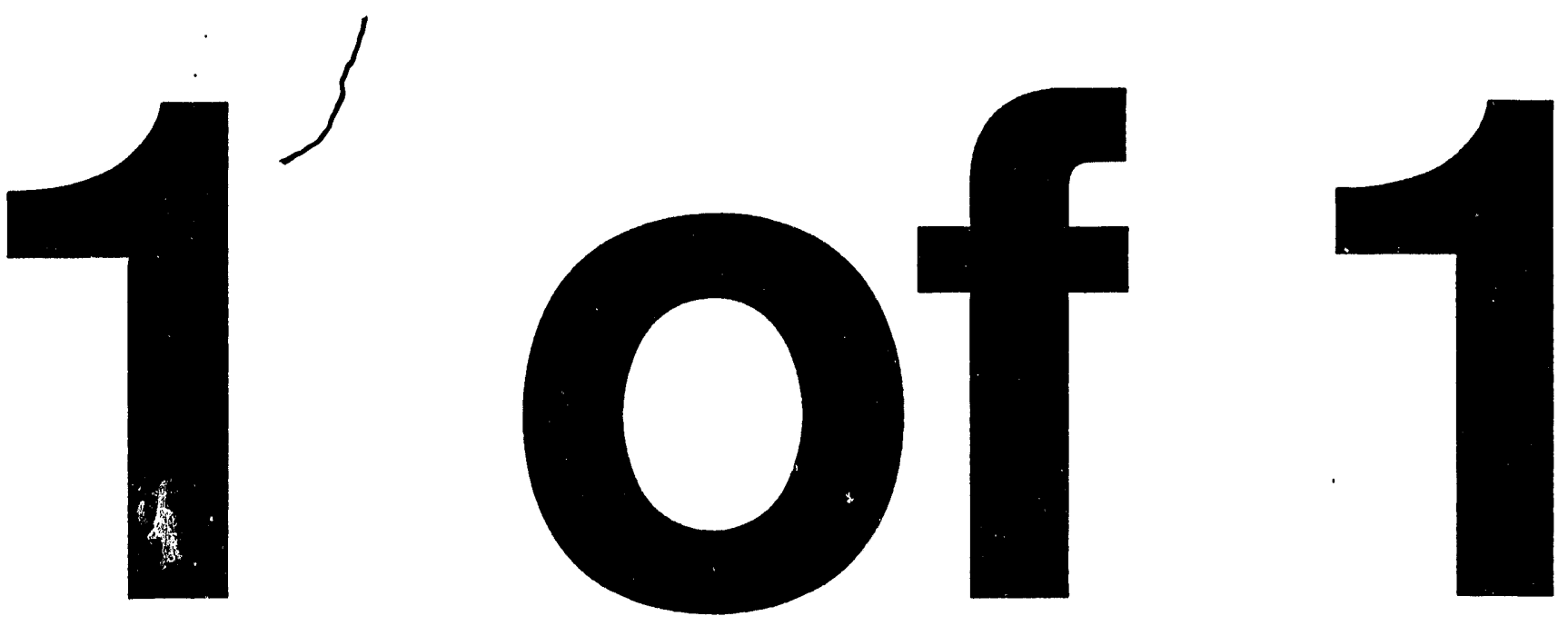


\section{Cleaning of Optical Components for High-Power Laser-Based Firing Systems}

Kansas City Division

B. D. Sparrow and

J. L. Hendrix

KCP-613-5218

Published August 1993

Topical Report

B. D. Sparrow, Project Leader

\section{CEIVLS \\ DCT 181993 \\ OSTI}




\section{DISCLAIMER}

This report was prepared as an account of work sponsored by an agency of the United States Government. Neither the United States Government nor any agency thereof, nor any of their employees, makes any warranty, express or implied, or assumes any legal liability or responsibility for the accuracy, completeness, or usefulness of any information, apparatus, product, or process disclosed, or represents that its use would not infringe privately owned rights. Reference herein to any specific commercial product. process, or service by trade name, trademark, manufacturer, or otherwise, does not necessarily constitute or imply its endorsement, recommendation, or favoring by the United States Government or any agency thereof. The views and opinions of authors expressed herein do not necessarily state or reflect those of the United States Government or any agency thereof.

Printed in the United States of America.

This report has been reproduced from the best available copy.

Available to DOE and DOE contractors from the Office of Scientific and Technical Information, P. O. Box 62, Oak Ridge, Tennessee 37831; prices available from (615) 576-8401, FTS 626-8401.

Available to the public from the National Technical Information Service, U. S. Department of Commerce, 5285 Port Royal Rd., Springfield, Virginia 22161.

A prime contractor with the United States Department of Energy under Contract Number DE-ACO4-76-DP00613.
AlliedSignal Inc. Kansas City Division P.O. Box 419159 Kansas City, Missouri 64141-6159 
KCP. $613-5218$

Distribution Category UC-706

\section{CLEANING OF OPTICAL COMPONENTS FOR}

HIGH-POWER LASER-BASED FIRING SYSTEMS

B. D. Sparrow and

J. L. Hendrix

Published August 1993

Topical Report

B. D. Sparrow, Project Leader

Project Team:

G. W. Bohnert

T. E. Hand

J. L. Hendrix

G. J. Meier

G. L. Morelli

R. A. Paiva

B. J. Rich

P. D. Sundvold 


\section{Contents}

Section . Page

Abstract $\ldots \ldots \ldots \ldots \ldots \ldots \ldots \ldots \ldots \ldots \ldots \ldots \ldots \ldots \ldots \ldots$

Summary $\ldots \ldots \ldots \ldots \ldots \ldots \ldots \ldots \ldots \ldots \ldots \ldots \ldots \ldots$

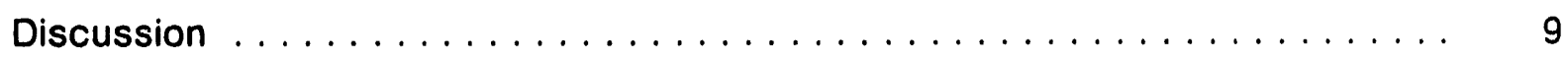

Scope and Purpose $\ldots \ldots \ldots \ldots \ldots \ldots \ldots \ldots \ldots \ldots \ldots \ldots$



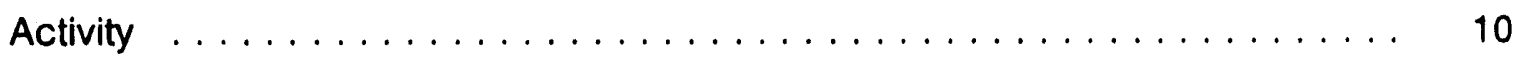

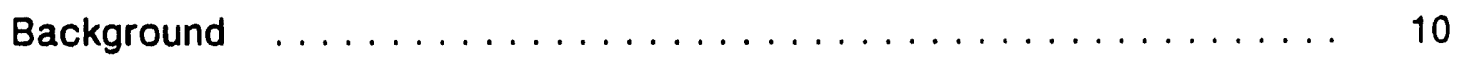

Review of DoD Cleaning Specifications $\ldots \ldots \ldots \ldots \ldots \ldots$

Alternative Cleaning/Surface Preparation Materials and Methods . . . . 17

Requirements on Supplies for Cleaning Optics $\ldots \ldots \ldots \ldots \ldots$



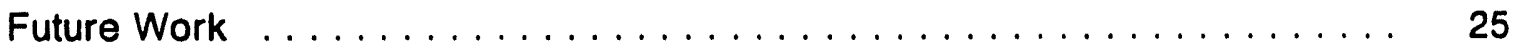

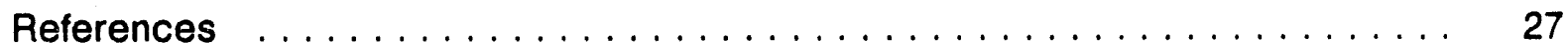




\section{Tables}

Number

Page

1 Comparison of Typical DOD and DOE Requirements for Laser-Based Systems That Indicate the Need for Further Process Development and Process Verification in the More Demanding Environments of the Nuclear Weapons Stockpile

2 Materials From MIS-23542 and MIS-35707 Shown With Their Acceptability to ES\&H Concerns and Alternate Cleaning Materials

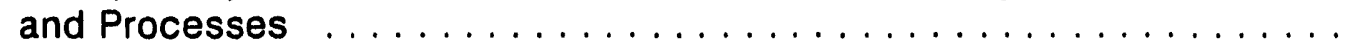

3 Cleaning Procedures for Various Materials With Recommended Alternatives Which Must Be Evaluated

4 Surface Preparation for Bonding Procedures for Various Materials With Recommended Alternatives Which Must Be Evaluated

5 Cleaning Optics for Laser-Based Systems Requiring Strict Attention to Details 


\begin{abstract}
This report discusses the progress of AlliedSignal Inc., Kansas City Division $(K C D)$, in addressing the issues of cleaning of hardware and optical components for laser-based firing sets. These issues are acceptability of cleaning processes and techniques of other government programs to the quality, reliability, performance, stockpile life, materials compatibility issues, and, perhaps most important, environmentally conscious manufacturing requirements of the Department of Energy (DOE). A review of "previous cleaning art" is presented using Military Standards (MIL STDs) and Military Interim Specifications (MISs) as well as empirical data compiled by the authors. Observations on processes and techniques used in building prototype hardware and plans for future work are presented.
\end{abstract}

\title{
Summary
}

Cleaning of laser hardware and optical components for laser-based systems is a critical collection of processes and procedures. Historically the importance of cleaning/cleanliness and contamination control cannot be over emphasized. Improperly cleaned hardware has been responsible for failures at the next assembly level of laser-based optical systems, and outgassing and material incompatibility issues have caused failures in fielded military laser-based systems.

This report discusses the progress of AlliedSignal Inc., Kansas City Division (KCD), in addressing the issues of cleaning of hardware and optical components for laser-based firing sets. These issues are acceptability of the cleaning processes and techniques of other government programs to the quality, reliability. performance, stockpile life, materials compatibility issues, and, perhaps most important, environmentally conscious manufacturing requirements of the Department of Energy (DOE).

The cleaning processes and procedures used for the U. S. Army laser programs were obtained through the custodian of those documents at Redstone Arsenal. We reviewed the materials and chemicals referenced by the Army document MIS-23542, and several chemicals were determined to be unacceptable due to an increased emphasis on environmentally conscious manufacturing and a focus on environment, safety and health (ES\&H). A review of the existing processes for cleaning hardware for high-voltage electrical systems, which are also cleanliness critical, was made to determine how close these might be to acceptable for use in laser-basec' systems. The results are presented and the approach for both determining and verifying acceptable cleaning procedures, both to ES\&H and performance (quality, reliability, stockpile 
life, material compatibility, etc.), are presented.

In addition, KCD has now built several lasers and opticial firesets using a combination of cleaning techniques for the various components and observations based on that experience, which is also presented. 


\section{Discussion}

\section{Scope and Purpose}

The goal of the cleaning processes for hardware and optical components for the laser-based firing systems project is to prepare a set of processes and procedures that will ensure maximum performance, stockpile life, reliability, and materials compatibility within the constraints of Environment, Safety and Health (ES\&H) and environmentally conscious manufacturing in order to realize a significant improvement in nuclear surety.

- Performance means that optical components from laser rods to wedges and lenses to fiber optics can repeatably and reliably transmit optical peak power densities of 100 megawaits per square centimeter to the order of 5 gigawatts per square centimeter, depending on their location in the optical train.

- Reliability means being able to "perform" at any time and every time without failure.

- Stockpile life means that the performance and reliability must remain within acceptable limits over as much as 30 years of standby deployment.

- Materials compatibility means that each material used in the system, from casting materials to plastic parts and from solvents to wire insulation, must not interact in any way to form contaminants, either particulates or outgassing vapors, that can collect on the optical components and cause laser-induced damage or plasma formation that would interfere with performance, reliability, or stockpile life.

- ES\&H constraints represent our commitment to 1) the preservation and conservation of our natural environment, 2) the health and safety of our community, and 3) the health and safety of our work force.

- Environmentally conscious manufacturing means that we will not intentionally use materials, processes, or practices that will harm our natural environment, and, in addition, engineering controls will be used to systematically assess our operations to minimize the risk of unintentional harm to the environment.

The project as a whole is to satisfy all of these requirements and constraints. This report gives the current progress and the planned work for obtaining these goals.

\section{Prior Work}

The Department of Defense (DoD) has been buying laser-based systems almost since the first successful laser was built in 1960 by Ted Maiman at the Hughes Research Labs. As a result of those thirtyplus years of the DoD's buying tens of thousands of laser systems for often harsh military applications and environments, specifications, processes, and procedures have emerged that have met the DoD's requirements for performance and reliability. The needs of the optical firing 
systems for the Department of Energy's (DOE) weapons program are more demanding on several fronts. For example, the typical optical peak power density in a military laser system is about 100 megawatts per square centimeter while segments of the optical firing system must pass gigawatts per square centimeter. Another example is the storage and/or operational lifetimes. For a typical DoD system the operational lifetime is on the order of seven years while a DOE system may sit in the stockpile for longer than 30 years. Thus, materials incompatibilities have longer to materialize.

In addition to these use issues, the climate of tolerance for use of processes and materials that could possibly harm the environment has changed. What was acceptable in the 1980s can now be against state and federal laws and violate international treaties. Thus, substitute materials, which also mean processes and procedures, must be changed. The resulting processes must be verified, that is, proven, to meet or exceed the performance, reliability, materials compatibility, stockpile life, and acceptability to environmental concerns.

The best known cleaning document is the U. S. Army's MIS-23542 (Missile Interim Specification) for cleaning of laser hardware. 1 (MIS-35707, Preparation of Surfaces for Adhesive Bonding, was also reviewed. $)^{2}$ We have used MIS-23542 as a starting point for the development of a process/procedure that will address all of the issues relevant to the DOE mission. An additional issue is that the Army MIS does not address cleaning of optical fibers.

\section{Activity}

\section{Background}

Optical firing systems are a cornerstone to improving the safety of our nuclear stockpile. Those optical firesets take a step beyond conventional electrical firesets by introducing a laser, stronglinks with optical elements, splitter/coupler modules. and fiber optic cables. Each of these additional elements/modules has optical components within it. Optical firing sets require the generation of hundreds of millijoules of energy in the order of ten nanoseconds which then pass through the system spread over diameters from a few millimeters down to less than half a millimeter. This produces optical peak power densities in the range of 100 megawatts per square centimeter to over five gigawatts per square centimeter. These energy levels are capable of drilling through steel, and if contamination is present on any of these optical surfaces, laser-induced damage to the component is likely to occur which can cause a range of consequences, from no effect to compiete system failure. Thus, the need exists for cleaning processes and procedures that will minimize, if not eliminate, the risk of optically induced damage.

Cleaning of laser hardware and optical components for laser-based systems is a critical collection of processes and procedures. Historically the importance of cleaning/cleanliness and contamination control cannot be over emphasized. Improperly cleaned hardware has been responsible for failures at the next assembly level of laser-based optical systems, and outgassing and material incompatibility issues have caused failures in fielded military laser-based systems. 
This report discusses the progress of AlliedSignal Inc., Kansas City Division (KCD), in addressing the issues of cleaning of hardware and optical components for laser-based firing sets. These issues are acceptability of cleaning processes and techniques of other government programs to the quality, reliability, performance, stockpile life, materials compatibility issues, and, perhaps most important, environmentally conscious manufacturing requirements of the DOE.

The cleaning processes and procedures used for the $U$. S. Army laser programs were obtained through the custodian of those documents at Redstone Arsenal. 1,2,3 We reviewed the materials and chemicals referenced by the Army document MIS-23542, and several chemicals were determined to be unacceptable due to an increased emphasis on environmentally conscious manufacturing and a focus on environment, safety, and health (ES\&H). 1 A review was made of the currently existing processes for cleaning hardware for highvoltage electrical systems, which are also cleanliness critical, to determine how close these might be to acceptable for use in laser-based systems. The results are presented and the plans for both determining and verifying acceptable cleaning procedures, both to ES\&H and performance (quality, reliability, stockpile life, material compatibility, etc.), are presented.

In addition, KCD has now built several lasers and optical firesets using a combination of cleaning techniques for the various components and observations based on that experience, which is also presented.

\section{Revlew of DoD Cleaning Specifications}

The U. S. Army Missile Interim Specifications, Cleaning Laser System Hardware, MIS-23542, Revision P, dated 7 March 1988, and Preparation of Surfaces for Adhesive Bonding. MIS-35707, represent thoroughly proven processes for DOD laser-based systems that must meet the iypical requirements listed in Table 1.1,2 Also listed in Table 1 are the parameters that a comparable DOE laser firing system would require.

The need to verify that the MIS cleaning processes are adequate for DOE applications would be required regardless of the crackdown on volatile/toxic chemicals used in the aforementioned processes. However, the addition of the ES\&H concerns makes the project more involved because we cannot only verify/prove the existing processes but must determine a new set of processes that are as good as the old ones. The new processes must be ES\&H acceptable, and we must also verify that they are adequate for the new requirements.

A summary list of materials is shown in Table 2. The material safety data sheets (MSDSs) for those chemicals have been obtained and reviewed. The KCD ES\&H group also reviewed the processes for ES\&H acceptability. Table 2 also indicates the materials that are currently acceptable and unacceptable. Because there are no straightforward substitutions of materials for those deemed unacceptable, process changes will be required. not just materials changes. To that end, Table 3 presents potential substitute processes for each unacceptable material:process.

Text continued on page 17. 
Table 1. Comparison of Typical DoD and DOE Requirements for Laser-Based Systems That Indicate the Need for Further Process Development and Process Verification in the More Demanding Environments of the Nuclear Weapons Stockpile

\begin{tabular}{|c|c|c|c|}
\hline Specification & $\begin{array}{l}\text { Typical DoD } \\
\text { Requirement }\end{array}$ & $\begin{array}{l}\text { Typical DOE } \\
\text { Requirement }\end{array}$ & $\begin{array}{l}\text { Driver for Cleaning Process } \\
\text { Enhancement or Verification }\end{array}$ \\
\hline $\begin{array}{l}\text { Peak Power } \\
\text { Density }\end{array}$ & $400 \mathrm{MW} / \mathrm{cm}^{2}$ & $0.1-10 \mathrm{GW} / \mathrm{cm}^{2}$ & $\begin{array}{l}\text { Increase in peak power density } \\
\text { makes cleanliness much more } \\
\text { critical because contamination } \\
\text { means damage and degraded } \\
\text { performance. }\end{array}$ \\
\hline $\begin{array}{l}\text { Lifetime } \\
\text { (Storage } \\
\text { and/or } \\
\text { Operational) }\end{array}$ & $7-10$ Years & $30+$ Years & $\begin{array}{l}\text { Materials compatibility issues are } \\
\text { more pronounced with longer } \\
\text { interaction times. }\end{array}$ \\
\hline $\begin{array}{l}\text { Maintenance } \\
\text { Cycle }\end{array}$ & Periodic & None & $\begin{array}{l}\text { DoD systems are used or at least } \\
\text { tested continuously, which allows for } \\
\text { maintenance while the DOE systems } \\
\text { must sit for years and then work the } \\
\text { first time, every time. }\end{array}$ \\
\hline $\begin{array}{l}\text { Repetition } \\
\text { Rate }\end{array}$ & $0.7 \mathrm{~Hz}$ to $1 \mathrm{KHz}$ & One Shot & $\begin{array}{l}\text { Missing one shot is not an issue for a } \\
\text { repetition rate system, but in a one- } \\
\text { shot device there is only one } \\
\text { opportunity. If there is a contaminant } \\
\text { on an optical surface that burns or } \\
\text { causes a plasma to form, the energy } \\
\text { available from that one shot may be } \\
\text { lost and not allow the detonator to } \\
\text { function. }\end{array}$ \\
\hline Shock & $225 \mathrm{~g}, 11 \mathrm{~ms}$ & $3000 \mathrm{~g}, 1 \mathrm{~ms}$ & $\begin{array}{l}\text { Bonding surface preparation } \\
\text { becomes more important because } \\
\text { better adhesion is required for the } \\
\text { larger shocks. }\end{array}$ \\
\hline Vibration & $10 \mathrm{~g}$ & $27 \mathrm{~g}$ & $\begin{array}{l}\text { Higher vibration again stresses bond } \\
\text { joints more and can also lead to } \\
\text { increased particulate contamination if } \\
\text { systems are not properly designed } \\
\text { and assembled. }\end{array}$ \\
\hline
\end{tabular}


Table 2. Materials From MIS-23542 and MIS-35707 Shown With Their Acceptability to ES\&H Concerns and Alternate Cleaning Materials and Processes

\begin{tabular}{|c|c|}
\hline Material & $\begin{array}{l}\text { Acceptability or Reason for Unacceptability } \\
\text { (Diamond Label: Health/Fire/Reactivity) }\end{array}$ \\
\hline Isopropyl Alcohol (IPA) & $\begin{array}{l}\text { Acceptable } \\
(1 / 3 / 0)\end{array}$ \\
\hline Ethyl Alcohol (Ethanol) & $\begin{array}{l}\text { Acceptable } \\
(1 / 3 / 0)\end{array}$ \\
\hline Methyl Alcohol (Methanol) & $\begin{array}{l}\text { Acceptable } \\
(1 / 3 / 0)\end{array}$ \\
\hline Methyl Ethyl Ketone (MEK) & $\begin{array}{l}\text { Acceptable } \\
(1 / 3 / 0)\end{array}$ \\
\hline Hexane & $\begin{array}{l}\text { Acceptable } \\
(1 / 3 / 0)\end{array}$ \\
\hline Acetone & $\begin{array}{l}\text { Acceptable } \\
(1 / 3 / 0)\end{array}$ \\
\hline 1,1,1 Trichloroethane & $\begin{array}{l}\text { Unacceptable--Ozone Depleter } \\
(2 / 1 / 1)\end{array}$ \\
\hline Toluene & $\begin{array}{l}\text { Unacceptable } \\
(2 / 3 / 0)\end{array}$ \\
\hline Basic-H (Detergent) & $\begin{array}{l}\text { Unacceptable } \\
(1 / 0 / 0)\end{array}$ \\
\hline Turco 5078 (Alkaline Cleaner) & $\begin{array}{l}\text { Acceptable } \\
(2 / 0 / 1)\end{array}$ \\
\hline $\begin{array}{l}\text { Turco } 4215 \text { NC-LT } \\
\text { (Alkaline Cleaner) }\end{array}$ & $\begin{array}{l}\text { Acceptable } \\
(2 / 0 / 1)\end{array}$ \\
\hline $\begin{array}{l}\text { Oakite HD-126 } \\
\text { (Alkaline Cleaner) }\end{array}$ & $\begin{array}{l}\text { Acceptable } \\
(3 / 0 / 0 !\end{array}$ \\
\hline $\begin{array}{l}\text { Cee Bee MX39G } \\
\text { (Alkaline Cleaner) }\end{array}$ & $\begin{array}{l}\text { Unacceptable--Contains Hexavalent Chromium, Listed } \\
\text { in the California Safe Drinking Water and Toxic } \\
\text { Enforcement Act as. Hazardous } \\
(2 / 0 / 0)\end{array}$ \\
\hline Dirl-lum 603 (Alkaline Cleaner) & $\begin{array}{l}\text { Acceptable } \\
(1 / 0 / 1)\end{array}$ \\
\hline Oakite 33 (Acidic Cleaner) & $\begin{array}{l}\text { Acceptable } \\
(2 / 0 / 1)\end{array}$ \\
\hline Hydrofluoric Acid & $\begin{array}{l}\text { Acceptable } \\
(4 / 0 / 0)\end{array}$ \\
\hline
\end{tabular}


Table 2 Continued. Materials From MIS-23542 and MIS-35707 Shown With Their Acceptability to ES\&H Concerns and Alternate Cleaning Materials and Processes

\begin{tabular}{|c|c|}
\hline Material & $\begin{array}{l}\text { Acceptability or Reason for Unacceptability } \\
\text { (Diamond Label: Health/Fire/Reactivity) }\end{array}$ \\
\hline Hydrochloric Acid & $\begin{array}{l}\text { Acceptable } \\
(3 / 0 / 0)\end{array}$ \\
\hline Nitric Acid & $\begin{array}{l}\text { Acceptable } \\
(3 / 0 / 1)\end{array}$ \\
\hline Phosphoric Acid & $\begin{array}{l}\text { Acceptable } \\
(2 / 0 / 2)\end{array}$ \\
\hline Sulfuric Acid & $\begin{array}{l}\text { Acceptable } \\
(3 / 0 / 2)\end{array}$ \\
\hline Chromic Acid & $\begin{array}{l}\text { Unacceptable } \\
(3 / 0 / 1)\end{array}$ \\
\hline $\begin{array}{l}\text { Sodium Phosphate } \\
\text { Tribasic } \\
\text { Anydrous } \\
\text { Dodecahydrate Monohydrate }\end{array}$ & $\begin{array}{l}\text { Acceptable } \\
(2 / 0 / 0) \\
(2 / 0 / 0) \\
(2 / 0 / 0) \\
(2 / 0 / 0)\end{array}$ \\
\hline Trisodium Phosphate & $\begin{array}{l}\text { Acceptable } \\
(2 / 0 / 1)\end{array}$ \\
\hline Sodium Dichromate & $\begin{array}{l}\text { Unacceptable } \\
(1 / 0 / 1)\end{array}$ \\
\hline Sodium Fluoride & $\begin{array}{l}\text { Acceptable } \\
(3 / 0 / 0)\end{array}$ \\
\hline Sodium Hydroxide & $\begin{array}{l}\text { Acceptable } \\
(3 / 0 / 1)\end{array}$ \\
\hline Sodium Hypochlorite & $\begin{array}{l}\text { Acceptable } \\
(3 / 0 / 1)\end{array}$ \\
\hline Sodium Metasilicate & $\begin{array}{l}\text { Acceptable } \\
(2 / 0 / 0)\end{array}$ \\
\hline Sodium Pyrophosphate & $\begin{array}{l}\text { Acceptable } \\
(2 / 0 / 1)\end{array}$ \\
\hline Ferric Chloride & $\begin{array}{l}\text { Acceptable } \\
(2 / 0 / 0)\end{array}$ \\
\hline
\end{tabular}


Table 3. Cleaning Procedures for Various Materials With Recommended Alternatives Which Must Be Evaluated

\begin{tabular}{|c|c|c|}
\hline Material & Abbreviated Process Description & Alternative Identified* \\
\hline Glass & $\begin{array}{l}\text { - Vapor degrease in } 1,1,1 \text { trichloro- } \\
\text { ethane solvent. } \\
\text { - Wipe or flush with acetone. } \\
\text { - Nitrogen blow or air dry. }\end{array}$ & $\begin{array}{l}\text { - Modified wipe down } \\
\text { solution MS } 4702424 \\
\text { without OT-75 } \\
\text { surfactant. }\end{array}$ \\
\hline $\begin{array}{l}\text { Glass-Bonded } \\
\text { Assemblies }\end{array}$ & $\begin{array}{l}\text { - Wipe with ethanol. } \\
\text { - Air dry. }\end{array}$ & $\begin{array}{l}\text { - MS } 4702424 \text { without } \\
\text { OT-75 surfactant. }\end{array}$ \\
\hline $\begin{array}{l}\text { Polarizers, Laser } \\
\text { Rods, LiNbO } \\
\text { Crystals, and } \\
\text { Samarium Glass }\end{array}$ & $\begin{array}{l}\text { - Immerse/flush/wipe in } \\
\text { hexane/acetone mix. } \\
\text { - Air dry. } \\
\text { - Wipe or flush with acetone. } \\
\text { - Air dry. }\end{array}$ & - OK. \\
\hline $\begin{array}{l}\text { Aluminum, } \\
\text { Titanium, and } \\
\text { Molybdenum }\end{array}$ & $\begin{array}{l}\text { Vapor degrease in 1,1,1 trichloro- } \\
\text { ethane. } \\
\text { - Scrub with brush as necessary. } \\
\text { - } \text { Rinse with DI water. } \\
\text { - MX39G or Basic-H. } \\
\text { - Rinse/soak/rinse in DI water; solvent } \\
\text { flush with IPA. } \\
\text { - Nitrogen blow dry. } \\
\text { - Vapor degrease in 1,1,1 trichloro- } \\
\text { ethane. } \\
\text { - Nitrogen blow dry. } \\
\text { - Vacuum oven bake for } 72 \text { hours. } \\
\text { - Vapor degrease in } 1,1,1 \text { trichloro- } \\
\text { ethane. } \\
\text { Nitrogen blow dry. }\end{array}$ & $\begin{array}{l}\text { Wipe/flush in } \\
\text { hydrocarbon solvent } \\
\text { such as Actrel } 4493 \mathrm{~L} \\
\text { or } 3338 \mathrm{~L} \text {. } \\
\text { Ultrasonic clean in } \\
\text { alkaline cleaner, } \\
\text { followed by DI water } \\
\text { rinse and } \mathrm{N}_{2} \text { oven dry. } \\
\text { - Solvent flush in IPA. }\end{array}$ \\
\hline $\begin{array}{l}\text { Heat Exchanger } \\
\text { Parts }\end{array}$ & $\begin{array}{l}\text { - Soak/flush in toluene twice. } \\
\text { Nitrogen blow dry. } \\
\text { Ultrasonic clean (Cee Bee MX39G, } \\
\text { Basic-H, Oakite } 33 \text { and HD-126, } \\
\text { Dirl-lum 603, or } 5078 \text { ). } \\
\text { - Rinse/soak'rinse with DI water. } \\
\text { - Nitrogen blow dry. } \\
\text { - Rinse with IPA or ethanol. } \\
\text { Vacuum oven dry. }\end{array}$ & - OK except toluene. \\
\hline
\end{tabular}

NOTE: The alternative processes listed are not proven acceptable but are merely options that are thought to be more environmentally safe. 
Table 3 Continued. Cleaning Procedures for Various Materials With Recommended Alternatives Which Must Be Evaluated

\begin{tabular}{|c|c|c|}
\hline Material & Abbreviated Process Description & Alternative identified ${ }^{\star}$ \\
\hline Copper & $\begin{array}{l}\text { - Vapor degrease in 1,1,1 trichloro- } \\
\text { ethane. } \\
\text { - Nitrogen blow dry, ultrasonic clean } \\
\text { in Oakite } 33 \text {. } \\
\text { - Rinse/soak/rinse with DI water. } \\
\text { - Rinse with IPA or ethanol. } \\
\text { - Nitrogen blow dry. } \\
\text { - Vapor degrease in } 1,1,1 \text { trichloro- } \\
\text { ethane. } \\
\text { - Nitrogen blow dry. } \\
\text { - Vacuum oven bake for } 16 \text { hours. } \\
\text { - Vapor degrease in } 1,1,1 \text { trichloro- } \\
\text { ethane. } \\
\text { - Nitrogen blow dry. }\end{array}$ & $\begin{array}{l}\text { OK except } 1,1,1 \\
\text { trichloroethane. }\end{array}$ \\
\hline $\begin{array}{l}\text { Corrosion- } \\
\text { Resistant Steel }\end{array}$ & $\begin{array}{l}\text { - Same as copper, except ultrasonic } \\
\text { clean in Oakite HD-126. }\end{array}$ & $\begin{array}{l}\text { - Ultrasonic clean in } \\
\text { alkaline solution. }\end{array}$ \\
\hline $\begin{array}{l}\text { Steel, Nickel, and } \\
\text { Chromium }\end{array}$ & $\begin{array}{l}\text { - Same as copper, except ultrasonic } \\
\text { clean in Dirl-lum } 603 \text {. }\end{array}$ & $\begin{array}{l}\text { - OK except chrome } \\
\text { may be affected by } \\
\text { alkaline cleaners. }\end{array}$ \\
\hline Gold & $\begin{array}{l}\text { - Same as copper, except ultrasonic } \\
\text { clean in Turco } 5078 \text {. }\end{array}$ & - OK. \\
\hline $\begin{array}{l}\text { Elastomers, } \\
\text { Plastics, and } \\
\text { Ceramics }\end{array}$ & $\begin{array}{l}\text { - Wipe with cloth or brush as } \\
\text { necessary. } \\
\text { - Ultrasonic clean in Basic-H. } \\
\text { - Rinse/soak/rinse with DI water. } \\
\text { - Rinse with IPA or ethanol. } \\
\text { - Nitrogen blow dry. } \\
\text { - Vapor degrease in } 1,1,1 \text { trichloro- } \\
\text { ethane. } \\
\text { - Nitrogen blow dry. } \\
\text { - Vacuum oven bake for } 16 \text { hours. } \\
\text { - Vapor degrease in } 1,1,1 \text { trichloro- } \\
\text { ethane. }\end{array}$ & $\begin{array}{l}\text { Mild alkaline (LPS, } \\
\text { Oakite Inproclean } \\
\text { 1300 Dara-Clean 282, } \\
\text { or Quaker 624GD. } \\
\text { - Hot waier rinse. } \\
\text { - Blow dry. }\end{array}$ \\
\hline
\end{tabular}

NOTE: The alternative processes listed are not proven acceptable but are merely options that are thought to be more environmentally safe. 
Table 3 Continued. Cleaning Procedures for Various Materials With Reciommended Alternatives Which Must Be Evaluated

\begin{tabular}{|c|c|c|}
\hline Material & Abbreviated Process Description & Alternative Identified* \\
\hline $\begin{array}{l}\text { Silicones and } \\
\text { O-Rings }\end{array}$ & $\begin{array}{l}\text { - Wipe with cloth or brush as } \\
\text { necessary. } \\
\text { - Ultrasonic clean in Basic-H. } \\
\text { - Ninse with DI water. } \\
\text { - Nitrogen blow dry. } \\
\text { - Vacuum oven bake O-rings for } \\
120 \text { hours. } \\
\text { - Wipe with hexane. } \\
\text { - Nitrogen blow dry. }\end{array}$ & $\begin{array}{l}\text { - Alkalirie solution } \\
\text { (Dirl-lum 603). } \\
\text { - Hot water rinse. } \\
\text { - Vacuum bake. }\end{array}$ \\
\hline $\begin{array}{l}\text { Non-silicone } \\
\text { O-Rings }\end{array}$ & $\begin{array}{l}\text { - Wipe with cloth or brush as } \\
\text { necessary. } \\
\text { - Ultrasonic clean in Basic-H. } \\
\text { - Rinse/soak/rinse with DI water. } \\
\text { - Wipe with hexane. } \\
\text { - Nitrogen blow dry. }\end{array}$ & - OK. \\
\hline $\begin{array}{l}\text { Conformally } \\
\text { Coated } \\
\text { Assemblies }\end{array}$ & $\begin{array}{l}\text { - Scrub with brush, wet with IPA. } \\
\text { - Spray with IPA. } \\
\text { - Nitrogen blow or air dry. }\end{array}$ & - OK. \\
\hline $\begin{array}{l}\text { Conformally } \\
\text { Coated Wiring } \\
\text { Harnesses }\end{array}$ & $\begin{array}{l}\text { - Spray with IPA nitrogen. } \\
\text { - Blow or air dry. }\end{array}$ & - OK. \\
\hline $\begin{array}{l}\text { Resonator Pump } \\
\text { Cavity, Impeller } \\
\text { Motor, Samarium } \\
\text { Filter, and Clean } \\
\text { Parts }\end{array}$ & $\begin{array}{l}\text { - Wipe with hexane. } \\
\text { - Air dry. }\end{array}$ & - OK. \\
\hline
\end{tabular}

NOTE: The alternative processes listed are not proven acceptable but are merely options that are thought to be more environmentally safe.

\section{Alternative Cleaning/Surface Preparation Materials and Methods}

Several cleaning experts at KCD were contacted to review the processes for both cleaning and surface preparation for bonding. Table 3 lists the results from that cleaning processes review, and Table 4 presents the results from the surface preparation for bonding process review.

\section{Requirements on Supplies for Cleaning Optics}

Table 5 represents a tremendous amount of research as well as trial and error on the part of the laser/optics manufacturers to

Text continued on page 23. 
Table 4. Surface Preparation for Bonding Procedures for Various Materials With Recommended Alternatives Which Must Be Evaluated

\begin{tabular}{|c|c|c|}
\hline Material & $\begin{array}{l}\text { Abbreviated Bonding Surface } \\
\text { Preparation Process }\end{array}$ & Alternative Processes ${ }^{\star}$ \\
\hline Aluminum Alloys & $\begin{array}{l}\text { Vapor degrease in 1,1,1 trichloro- } \\
\text { ethane. } \\
\text { - Wipe with toluene or MEK. } \\
\text { Immerse in solution of the following: } \\
\text { - Tap water, } \\
\text { - Non-etch hot alkaline cleaner, } \\
\text { and } \\
\text { - Rinse with tap water. } \\
\text { Immerse in solution of the following: } \\
\text { - SI water, } \\
\text { - Sulfuric acid, and } \\
\text { - Sodium dichromate. } \\
\text { - Air or oven dry. }\end{array}$ & $\begin{array}{l}\text { - Ultrasonic clean in } \\
\text { neutral } \mathrm{pH} \text { solution } \\
\text { (Oakite, Inproclean } \\
\text { 1300, etc.). } \\
\text { - Follow with DI water } \\
\text { rinse. } \\
\text { - } \mathrm{N}_{2} \text { Oven dry. } \\
\text { - Wipe with IPA. }\end{array}$ \\
\hline $\begin{array}{l}\text { Aluminum Parts, } \\
\text { Assemblies: } \\
\text { Anodized } \\
\text { Aluminum; } \\
\text { Chemically } \\
\text { Treated Aluminum }\end{array}$ & $\begin{array}{l}\text { - Mask areas adjacent to bonding } \\
\text { surfaces. } \\
\text { - Scrub with institutional grade } \\
\text { abrasive cleaner; apply paste of the } \\
\text { following: } \\
\text { Sulfuric acid, } \\
\text { - Sodium dichromate, } \\
\text { - DI or tap water, and } \\
\text { - Microfine silica powder. } \\
\text { - Rinse with tap water, then DI water. } \\
\text { Air or oven dry. }\end{array}$ & $\begin{array}{l}\text { - Ultrasonic clean in DI } \\
\text { water with a } \\
\text { surfactant. } \\
\text { - Follow with DI water } \\
\text { rinse. } \\
\text { - Oven dry. }\end{array}$ \\
\hline $\begin{array}{l}\text { Anodized } \\
\text { Aluminum } \\
\text { (Alternate) }\end{array}$ & $\begin{array}{l}\text { Vapor degrease in 1,1,1 trichloro- } \\
\text { ethane. } \\
\text { - Wipe with toluene or MEK. } \\
\text { Mask areas adjacent to bonding } \\
\text { surfaces; scrub with institutional } \\
\text { grade abrasive cleaner. } \\
\text { - Rinse with tap water, then DI water. }\end{array}$ & $\begin{array}{l}\text { Wipe with IPA. } \\
\text { - Ultrasonic clean in DI } \\
\text { water with surfactant. } \\
\text { - Follow with DI water } \\
\text { rinse. } \\
\text { - } \mathrm{N}_{2} \text { oven dry. }\end{array}$ \\
\hline $\begin{array}{l}\text { Removal of } \\
\text { Anodizing }\end{array}$ & $\begin{array}{l}\text { - Strip anodizing in a solution of the } \\
\text { following: } \\
\text { - Chromic acid (essential } \\
\text { Constituent) } \\
\text { - Phosphoric acid, and } \\
\text { - Dl or tap water. }\end{array}$ & - Unknown. \\
\hline
\end{tabular}

"NOTE: The alternative processes listed are not proven acceptable but are merely options that are thought to be more environmentally safe. 
Table 4 Continued. Surface Preparation for Bonding Procedures for Various Materials With Recommended Alternatives Which Must Be Evaluated

\begin{tabular}{|c|c|c|}
\hline Material & $\begin{array}{l}\text { Abbreviated Bonding Surface } \\
\text { Preparation Process }\end{array}$ & Alternative Processes ${ }^{\star}$ \\
\hline Titanium & $\begin{array}{l}\text { - Wipe with toluene. } \\
\text { Pickle in a solution of the following: } \\
\text { - Nitric acid, } \\
\text { Hydrofluoric acid, and } \\
\text { - Tap water. } \\
\text { Imse with tap water. } \\
\text { following: } \\
\text { - Trisodium phosphate, } \\
\text { - Hodium fluoride, } \\
\text { - Taprofluoric acid, and } \\
\text { - Rinse/soak with tap water. } \\
\text { - Rinse with DI water. } \\
\text { - Air or oven dry. }\end{array}$ & $\begin{array}{l}\text { - Solvent (hexane or } \\
\text { actrel). } \\
\text { - Plasma Clean. } \\
\text { or } \\
\text { - Ultrasonic clean in } \\
\text { alkaline solution. } \\
\text { - DI water rinse. } \\
\text { - } \mathrm{N}_{2} \text { oven dry. }\end{array}$ \\
\hline Magnesium Alloys & $\begin{array}{l}\text { - Vapor degrease in 1,1,1 trichloro- } \\
\text { ethane. }\end{array}$ & - IPA wipe. \\
\hline Steel & $\begin{array}{l}\text { Remove scale, oxides, and other } \\
\text { contaminants; immerse in a solution } \\
\text { of the following: } \\
\text { - Sodium metasilicate, } \\
\text { - Sodium pyrophosphate, } \\
\text { - Sodium hydroxide, } \\
\text { - Tetting agent, and } \\
\text { - Rinse with tap water, then DI water. } \\
\text { - Air or oven dry. }\end{array}$ & $\begin{array}{l}\text { - Hot, strong alkaline } \\
\text { cleaner (Dynadet, } \\
\text { Castrol Kleen } 3625 \text { ). } \\
\text { - Rinse in DI water. } \\
\text { - Dry with nitrogen in } \\
\text { HEPA filter convection } \\
\text { oven. }\end{array}$ \\
\hline $\begin{array}{l}\text { Corrosion } \\
\text { Resistant Steel }\end{array}$ & $\begin{array}{l}\text { - Remove scale, oxides, and other } \\
\text { contaminants; etch in a solution of } \\
\text { the following: } \\
\text { Hydrochloric acid, } \\
\text { - Phosphoric acid, and } \\
\text { - Hydrofluoric acid. } \\
\text { - Ainse with tap water, then DI water. } \\
\text { - oven dry. }\end{array}$ & $\begin{array}{l}\text { - Hot, strong alkaline } \\
\text { cleaner (Dynadet, } \\
\text { Castrol Kleen } 3625 \text { ). } \\
\text { - Rinse in DI water. } \\
\text { - Dry with nitrogen in } \\
\text { HEPA filter convection } \\
\text { oven. }\end{array}$ \\
\hline
\end{tabular}

NOTE: The alternative processes listed are not proven acceptable but are merely options that are thought to be more environmentally safe. 
Table 4 Continued. Surface Preparation for Bonding Procedures for Various Materials With Recommended Alternatives Which Must Be Evaluated

\begin{tabular}{|c|c|c|}
\hline Material & $\begin{array}{l}\text { Abbreviated Bonding Surface } \\
\text { Preparation Process }\end{array}$ & Alternative Processes ${ }^{\star}$ \\
\hline $\begin{array}{l}\text { Plated Metals (Ni, } \\
\mathrm{Cr}, \mathrm{Cd}, \mathrm{Zn} \text {, cleaner } \\
\mathrm{Au}, \mathrm{Ag}, \mathrm{Rh}, \mathrm{Pt} \text { ) }\end{array}$ & $\begin{array}{l}\text { - Vapor degrease in } 1,1,1 \text { trichloro- } \\
\text { ethane. } \\
\text { - Scour with institutional grade } \\
\text { abrasive cleaner. } \\
\text { - Rinse with DI water. } \\
\text { - Air or oven dry. }\end{array}$ & $\begin{array}{l}\text { - Wipe with IPA. } \\
\text { - Scour with institutional } \\
\text { grade abrasive } \\
\text { cleaner. } \\
\text { - Rinse with DI water. } \\
\text { - Air or oven dry. }\end{array}$ \\
\hline Bare Copper & $\begin{array}{l}\text { - Vapor degrease in } 1,1,1 \text { trichloro- } \\
\text { ethane. } \\
\text { Dip in ferric chloride solution of the } \\
\text { following: } \\
\text { Ferric chloride, } \\
\text { Nitric acid, and } \\
\text { DI or tap water. } \\
\text { - Rinse with tap water, then DI water. } \\
\text { - Air or oven dry. }\end{array}$ & $\begin{array}{l}\text { Dip in ferric chloride } \\
\text { solution of the } \\
\text { following: } \\
\text { Ferric chloride, } \\
\text { Nitric acid, and } \\
\text { DI or tap water. } \\
\text { Rinse with tap water, } \\
\text { then DI water. } \\
\text { - Air or oven dry. }\end{array}$ \\
\hline Laminated Plastics & $\begin{array}{l}\text { - Light sanding. } \\
\text { - Scrub with institutional grade } \\
\text { abrasive cleaner. } \\
\text { - Rinse with tap or DI water. } \\
\text { - Air or oven dry. } \\
\text { or } \\
\text { - Soak in acetone as necessary. } \\
\text { or } \\
\text { - Clean with IPA or trichloroethane as } \\
\text { necessary. }\end{array}$ & - First option is OK. \\
\hline $\begin{array}{l}\text { Polyphenylene } \\
\text { Sulfide Plastics }\end{array}$ & $\begin{array}{l}\text { Vapor degrease in } 1,1,1 \text { trichloro- } \\
\text { ethane. } \\
\text { Immerse in a solution of the } \\
\text { following: } \\
\text { Chromium trioxide, } \\
\text { Sulfuric acid, and } \\
\text { DI water. } \\
\text { Rinse with tap water, then DI water. } \\
\text { or } \\
\text { - Vapor degrease in } 1,1,1 \text { trichloro- } \\
\text { ethane. } \\
\text { Plasma clean at } 75 \text { watts in oxygen } \\
\text { at } 1 \text { torr. } \\
\text { or } \\
\text { - Vapor degrease in } 1,1,1 \text { trichloro- } \\
\text { ethane. } \\
\text { - Wipe with toluene. } \\
\text { - Sand blast. } \\
\text { Blow off loose particles. }\end{array}$ & $\begin{array}{l}\text { - Mild alkaline } \\
\text { detergent. } \\
\text { - DI water rinse. }\end{array}$ \\
\hline
\end{tabular}

NOTE: The alternative processes listed are not proven acceptable but are merely options that are thought to be more environmentally safe. 
Table 4 Continued. Surface Preparation for Bonding Procedures for Various Materials With Recommended Alternatives Which Must Be Evaluated

\begin{tabular}{|c|c|c|}
\hline Material & $\begin{array}{l}\text { Abbreviated Bonding Surface } \\
\text { Prepąration Process }\end{array}$ & Alternative Processes ${ }^{\star}$ \\
\hline $\begin{array}{l}\text { Polyethylene and } \\
\text { Polypropylene } \\
\text { Plastics }\end{array}$ & $\begin{array}{l}\text { - Scrub with institutional grade } \\
\text { abrasive cleaner. } \\
\text { Rinse with tap water; rinse with } \\
\text { acetone. } \\
\text { - Soak in toluene/acetone mixture. } \\
\text { Immerse in a solution of the } \\
\text { following: } \\
\text { Sodium dicromate and } \\
\text { - Sulfuric acid. } \\
\text { - Ainse with tap water, then DI water. } \\
\text { - Air or oven dry. }\end{array}$ & - Plasma clean \\
\hline Polyimide Plastics & $\begin{array}{l}\text { - Scrub with institutional grade } \\
\text { abrasive cleaner. } \\
\text { - Rinse with tap water, then DI water. } \\
\text { - Oven dry. } \\
\text { - Sand blast as necessary. }\end{array}$ & - OK. \\
\hline $\begin{array}{l}\text { Polyethylene } \\
\text { Terephthalate Film } \\
\text { Plastics }\end{array}$ & $\begin{array}{l}\text { - Immerse in a solution of alkaline } \\
\text { cleaner. } \\
\text { - Rinse with water. } \\
\text { - Immerse in a solution of the } \\
\text { following: } \\
\text { - Sodium dicromate, } \\
\text { - Sulfuric acid, and } \\
\text { - DI water. } \\
\text { - Rinse with DI water. } \\
\text { Air or oven dry. }\end{array}$ & $\begin{array}{l}\text { - Alkaline clean. } \\
\text { - Rinse with DI water. } \\
\text { - Plasma or corona } \\
\text { treat. }\end{array}$ \\
\hline Polyimide & $\begin{array}{l}\text { - Scrub with institutional grade } \\
\text { abrasive cleaner. } \\
\text { - Rinse with tap or DI water. } \\
\text { or } \\
\text { - Wipe/rinse with MEK. } \\
\text { - Air dry. } \\
\text { or } \\
\text { Plasma clean in argon or helium at } \\
1 \text { to } 2 \text { torr with } 0.75 \text { to } 1.25 \text { w/in } 3 \text {. }\end{array}$ & - OK. \\
\hline
\end{tabular}

NOTE: The alternative processes listed are not proven acceptable but are merely options that are thought to be more environmentally safe. 
Table 4 Continued. Surface Preparation for Bonding Procedures for Various Materials With Recommended Alternatives Which Must Be Evaluated

\begin{tabular}{|c|c|c|}
\hline Material & $\begin{array}{l}\text { Abbreviated Bonding Surface } \\
\text { Preparation Process }\end{array}$ & Alternative Processes ${ }^{\star}$ \\
\hline $\begin{array}{l}\text { Rubber and } \\
\text { Elastomers } \\
\text { (Cyclization or } \\
\text { Cracking) }\end{array}$ & $\begin{array}{l}\text { - Clean with toluene. } \\
\text { - } \text { Clean with toluene or MEK. } \\
\text { - Ory. } \\
\text { - Clean with toluene or MEK. } \\
\text { - Immerse in sulfuric acid. } \\
\text { - Imash with DI water. } \\
\text { water. } \\
\text { - Wash with DI water. } \\
\text { - Air or oven dry. } \\
\text { Flexroll to produce cracks. } \\
\text { - or } \\
\text { Immerse in a solution of the } \\
\text { following: } \\
\text { - Tap water and } \\
\text { - Ninse with DI water. } \\
\text { - Oven dry. } \\
\text { Immerse in a solution of the } \\
\text { following: } \\
\text { - Sodium hypochlorite, } \\
\text { - Hydrochloric acid, and } \\
\text { - Dinse water. } \\
\text { - Oven dry. }\end{array}$ & $\begin{array}{l}\text { - Ultrasonic clean with } \\
\text { hot alkaline solution. } \\
\text { - Ultrasonic clean in DI } \\
\text { water. } \\
\text { Dry in HEPA filtered } \\
\text { dry nitrogen purged } \\
\text { oven. }\end{array}$ \\
\hline $\begin{array}{l}\text { Ceramics } \\
\text { Glass }\end{array}$ & $\begin{array}{l}\text { - Scrub with institutional grade } \\
\text { abrasive cleaner. } \\
\text { - Rinse with water. } \\
\text { - Air or oven dry. }\end{array}$ & - OK. \\
\hline Painted Surfaces & $\begin{array}{l}\text { - Scrub with institutional grade } \\
\text { abrasive cleaner. } \\
\text { - Rinse with tap water. } \\
\text { - Air or oven dry. } \\
\text { or } \\
\text { - Wipe with aliphatic naphtha or } \\
\text { methanol sand. }\end{array}$ & - OK. \\
\hline
\end{tabular}

NOTE: The alternative processes listed are not proven acceptable but are merely options that are thought to be more environmentally safe. 
Table 4 Continued. Surface Preparation for Bonding Procedures for Various Materials With Recommended Alternatives Which Must Be Evaluated

\begin{tabular}{|c|c|c|}
\hline Material & $\begin{array}{l}\text { Abbreviated Bonding Surface } \\
\text { Preparation Process }\end{array}$ & Alternative Processes ${ }^{\star}$ \\
\hline Optical Elements & $\begin{array}{l}\text { - Scour with paste of the following: } \\
\text { - Pumice, or calcium carbonate, } \\
\text { or unchlorinated abrasive } \\
\text { cleaner. } \\
\text { - Scrub with water. } \\
\text { - Rinse with DI water. } \\
\text { - Hinse with acetone. } \\
\text { - Oven dry. } \\
\text { or } \\
\text { - Vapor degrease in MEK, acetone, or } \\
1,1,1 \text { trichloroethane. }\end{array}$ & $\begin{array}{l}\text { Use } \mathrm{N}_{2} \text {-assisted HEPA } \\
\text { oven for particulate } \\
\text { protection when drying. }\end{array}$ \\
\hline
\end{tabular}

NOTE: The alternative processes listed are not proven acceptable but are merely options that are thought to be more environmentally safe.

determine what specification for such things as lens tissue and solvent bottles is adequate for laser manufacture. Each supply is listed with its material or specification and a brief description of why that specific item is required.

\section{Accomplishments}

The review of the cleaning Missile Interim Specifications (MIS) for laser hardware cleaning and surface preparation for bonding has been completed. Areas that require further analysis and/or material and process substitutions have been identified. We are cleaning prototype hardware and integrating it into operational systems with the processes identified in the MIS and others. That hardware has performed flawlessly in tests to date. The area of fiber optic cleaning process for high peak power density transmission has begun on prototype hardware with methods. inspection requirements, and materials identified. The optical component cleaning processes are generally unaffected by ES\&H issues, but the issues indicated in Table 1 require that even those processes must be verified. We have provided a documented overview of cleaning issues for laser-based systems and laid the groundwork for future efforts. Specifically, the plans that are presented in the next section (Future Work) represent the planning required to make the overall cleaning and surface preparation for bonding processes acceptable to both the ES\&H issues and to the more demanding requirements of nuclear weapons.

A significant accomplishment is the documentation of these issues and our staius to this point. This is not yet complete, but this document will serve as a guide for future work.

EPMB lab room cleanliness issues surfaced during the production of lasers and firing systems indicating that a clean room better than the Class 30,000 
Table 5. Cleaning Optics for Laser-Based Systems Requiring Strict Attention to Details

\begin{tabular}{|c|c|c|}
\hline Supply & Material/Specification & Reason for Specified Material \\
\hline Lens Tissue & $\begin{array}{l}\text { FED-STD-NNN-P40, } \\
\text { Class I, Type } 54\end{array}$ & $\begin{array}{l}\text { This is the only type and grade of lens } \\
\text { tissue that does not contain silicone. } \\
\text { Silicone will remain on optical components } \\
\text { and will also migrate over time. The result } \\
\text { is that the silicone will absorb laser energy } \\
\text { and cause optical components to damage. }\end{array}$ \\
\hline Solvent Bottles & $\begin{array}{l}\text { Teflon, Squeeze } \\
\text { Dispenser Bottles }\end{array}$ & $\begin{array}{l}\text { Glass bottles with ground glass stoppers } \\
\text { produce a fine glass grit that will scratch } \\
\text { optical coatings when they are wiped. } \\
\text { Other types of plastic bottles are not stable } \\
\text { in/containing typical hydrocarbon solvents } \\
\text { (hexane, acetone, methanol, ethanol). The } \\
\text { squeeze bottles should be small, and the } \\
\text { gooseneck-type tube will minimize the } \\
\text { accumulation of water into the solvent by } \\
\text { reducing the surface area exposed to air. }\end{array}$ \\
\hline Solvents & Spectrographic Grade & $\begin{array}{l}\text { Lesser solvent grades contain other } \\
\text { solvents, water and/or other contaminants } \\
\text { that can remain on optical surfaces and } \\
\text { are typically not removed during the } \\
\text { cleaning process. The result is that the } \\
\text { contaminants will absorb laser energy and } \\
\text { cause the optical components to damage. }\end{array}$ \\
\hline Finger Cots & $\begin{array}{l}\text { Inert in cleaning solvents, } \\
\text { non-powdered cots can } \\
\text { be conductive or } \\
\text { antistatic if they do not } \\
\text { react or transfer material } \\
\text { to parts being cleaned or } \\
\text { handled. }\end{array}$ & $\begin{array}{l}\text { The issues here are that 1) the finger cot } \\
\text { material must not be soluble in the solvent } \\
\text { used to clean the parts because that can } \\
\text { again cause laser damage to occur and } \\
\text { 2) the cots must not be powdered (talc) } \\
\text { because that powder can get on the optical } \\
\text { surfaces and cause laser damage. }\end{array}$ \\
\hline Air Gun Filters & Teflon Disk Type & $\begin{array}{l}\text { Other small inline gas filters can generate } \\
\text { particulate contamination themselves that } \\
\text { then is deposited on optical components } \\
\text { and will burn, causing catastrophic } \\
\text { damage. }\end{array}$ \\
\hline Air Gun Tubing & Teflon & $\begin{array}{l}\text { Most types of plastic tubing will release } \\
\text { plasticizers over time which deposit as a } \\
\text { contamination layer on the optical surfaces } \\
\text { and can cause catastrophic damage. }\end{array}$ \\
\hline
\end{tabular}


Table 5 Continued. Cleaning Optics for Laser-Based Systems Requiring Strict Attention to Details .

\begin{tabular}{|c|c|c|}
\hline Supply & Material/Specification & Reason for Specified Material \\
\hline Tweezers & Teflon & $\begin{array}{l}\text { Metal tweezers can scratch optical } \\
\text { coatings, and other types of plastics are } \\
\text { attacked by the solvents typically used in } \\
\text { cleaning optics, thus depositing a residue } \\
\text { of contaminant on the surface of the part } \\
\text { that can then cause catastrophic damage } \\
\text { when exposed to high fluence laser } \\
\text { radiation. }\end{array}$ \\
\hline $\mathrm{N}_{2}$ Gas & $\begin{array}{l}\text { Ultra-Pure Dry } \mathrm{N}_{2} \text { to } \\
\text { MIL-P.27401, Type 1. } \\
\text { Grade C or Better5 }\end{array}$ & $\begin{array}{l}\text { No water vapor or particulate } \\
\text { contamination occurs when cleaning } \\
\text { optics. }\end{array}$ \\
\hline Packaging & $\begin{array}{l}\text { Aclar 33C, } 2 \text {-mil, cleaned } \\
\text { to meet MSC-SPEC-C-25 } \\
\text { Level } 2 \text { or equivalent.6 } \\
\text { Double bag; seal each } \\
\text { bag separately. }\end{array}$ & $\begin{array}{l}\text { Again the concern is outgassing } \\
\text { contamination to the assemblies which can } \\
\text { cause laser-induced damage and } \\
\text { catastrophic failures in performance. }\end{array}$ \\
\hline
\end{tabular}

environment in that lab is required. The problems identified centered around airborne particulate contaminarits settling on the optical surfaces of the device and subsequent burning of those contaminants. Catastrophic damage has not been seen, but performance degradation was observed. In uther tests performed previously on a prototype firing system we discovered 1) that fiber optics seem to attract particulate contaminants and 2) that the contaminants did not cause damage to the fiber optic surfaces even at about 1 gigawatt per square centimeter peak power density. This lack of damage is likely due to the uncoated nature of the fiber optics and the extremely high surface finish quality of those fiber's from the KCD polishing process developed by Dr. Paul Klingsporn.7.8

\section{Future Work}

Candidate cleaning agents and processes have been identified for testing using environmentally safe cleaning methods of all materials covered in MIS-23542 and MIS-35707.

Testing will be accomplished using statistically significant sample sizes of each material to be cleaned and for each proposed process. These quantities will be determined in the course of the work using design of experiments.

Preliminary plans for testing will use a comparison of the cleaning methods called out in the laser hardware cleaning specification (MIS-23542) and the preparation for bonding specification (MIS-35707) to be used as a control group. The new, environmentally safe, methods of cleaning will constitute the test group. 
These two groups of like parts will then be analyzed using infrared spectrometry as detailed in section 4.4.1.1 of MIS-23542 as well as with FTIR (Fourier transform infrared spectrometry) methods. Optical parts will be further tested by laser damage resistance verification testing which in these systems is tire ultimate proof of acceptability (covered by G. L. Morelli in another report). 9 We hope to correlate FTIR results with LDRVT results.

Adhesive bonding tests using environmentally safe cleaning methods will be conducted. Data obtained from these tests will be compared to historical data to verify the acceptability of the new processes.

Upon completion of these tests, a cleaning process specification will be written that covers laser-based system hardwaio as well as optical fibers for high peak power applications. This process procedure will be both environmentally safe and proven adequate for the stringent requirements of the DOE weapons programs. 


\section{References}

1 MIS-23542 P, Cleaning Laser System Hardware, Missile Interim Specification, dated 7 March 1988. U.S. Army Missile Command, Redstone Arsenal, Huntsville, Alabama, EER MI-B2765 is the document caretaker.

2MIS-35707, Preparation of Surfaces for Adhesive Bonding, Missile Interim Specification, dated 22 Jan 1986. Redstone Arsenal EER MI-H0700-5 is the document caretaker.

3MIS-30420 C. Solvents, Laser System Cleaning, Missile Interim Specification, dated 29 Aug 1980. Redstone Arsenal EER MI-B2805 is the document caretaker.

4FED-STD-NNN-P-40, Lens Paper.

5Military Standard, Propellant Pressurizing Agent, Nitrogen.

6MSC-SPEC-C-25, Precision Packaging Materials Cleanliness.

7P. E. Klingsporn, Surface Preparation and Characterization of a $400 \mu \mathrm{m}$ Diameter Fused Silica Optical Fiber for Direct Optical Initiation (DOI) Applications (Topical Report).

Kansas City Division: KCP-613-4969, November 1992 (Available from NTIS).

8P. E. Klingsporn, Fabrication and Analysis of a Special Optical Connector Containing a 1/4-Inch Optical Fiber for DOI Tests (Topical Report). Kansas City Division:

KCP-613-5039, April 1993 (Available from NTIS).

9G. L. Morelli, Laser Induced Damage Testing: Equipment and Techniques (Topical Report). Kansas City Division: KCP-613-5080, July 1993 (Available from NTIS). 

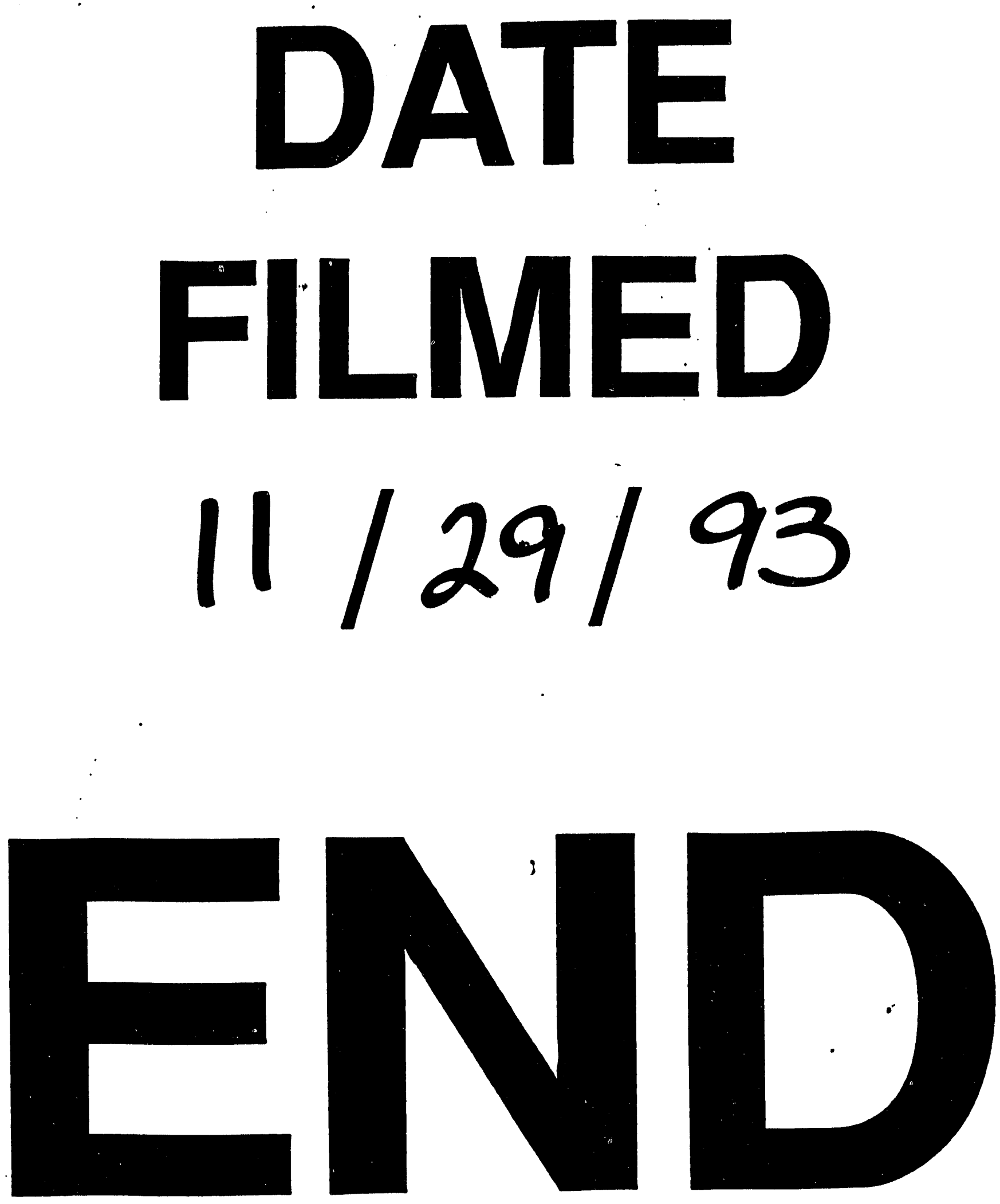
